\title{
IN MEMORY OF ROBERT GEORGIEVICH GLUSHKOV
}

\author{
Translated from Khimiko-Farmatsevticheskii Zhurnal, Vol. 47, No. 7, p. 56, July, 2013.
}

On July 10, 2013, after a short but severe illness, Editor in Chief of Khimiko-Farmatsevticheskii Zhurnal, Doctor of Chemical Sciences, Professor, Academician of the Russian Academy of Medical Sciences, Honored Scientist of Russia, Laureate of the USSR State Prize and the USSR Council of Ministers Prize Robert G. Glushkov died in his 84 th year.

For many years he was the Editor in Chief of Khimiko-Farmatsevticheskii Zhurnal, a member of the editorial board of the international journal Drugs of Future, a member of the Bureau of the Division of Biomedical Sciences of the Russian Academy of Medical Sciences, and a member of Pharmacology and Pharmacopeia State Committees of the Ministry of Health of the Russian Federation. Glushkov pursued his scientific interests for many years at the Center for Drug Chemistry, All-Russian Science Research Chemicopharmacological Institute (VNIKhFI)), a leading Russian center for drug creation. After graduating from the M. V. Lomonosov Moscow Institute of Fine Chemical Technology in 1953, Glushkov joined the VNIKhFI, where his enormous hard work and outstanding ability took him from the position of research assistant to institute director.

Glushkov's establishment as a scientist was aided by his postgraduate studies $(1958-1960)$ under the leadership of USSR State Prize laureate Professor O. Yu. Magidson - one of the founders of the Russian chemical-pharmaceutical industry. Glushkov defended his master's dissertation in organic chemistry in 1961. In $1965-1967$, Glushkov was a WHO-supported visiting scientist at the Universities of Cambridge and London, where he worked in the laboratories of Nobel Laureates Professor A. Todd and E. Chain. In 1971, Glushkov defended his doctoral thesis and in 1976 received the title of professor.

Engaging in both fundamental and applied areas of drug discovery, Glushkov and colleagues created a number of valuable original Russian agents with various different therapeutic actions: the antidepressants incazan, pyrazidole, and tetrindole, the antioxidants emoxypine and proxypine, and one of the world's first clinically used selective class III antiarrhythmic drugs, nibentan.

Glushkov's studies developing original and highly efficient production technologies for agents widely used in worldwide clinical practice (ketamine, lidocaine, piracetam, Ortofen, allopurinol, Clofelin, Tropindol, bupivacaine, aminostigmine, etc.) provided opportunities for these drugs to be produced in Russia.

These studies, summarized in two monographs and more than 160 Russian and foreign patents and more than 300 scientific publications, are well known in Russia and abroad.

After becoming Director General of the Center for Drug Chemistry, All-Russian Science Research Chemicopharmacological Institute, Glushkov not only led the organizational work of this large multidisciplinary institution, but also introduced active management of its research activities, taking direct part in all the major scientific and applied research. The main scientific achievements made under the leadership of Glushkov include:

a whole cycle of reports on the study, development and introduction to industry and medical practice of the drug arbidol an antiviral drug with unique immunomodulatory, interferon-inducing, and antioxidant properties, which is effective not only in the treatment of viral diseases, but also other diseases (post-operative infections, tuberculosis, etc.) and is currently the leading drug on the Russian pharmaceutical market;

the creation of original Russian psychotropic drugs - tetracyclic antidepressants, i.e., pyrazinocarbazole and pyrazinocarboline derivatives such as pyridazole, incazan, and tetrindole, which have better spectra of activity and greater efficacy and tolerance than non-Russian drugs;

the creation of the original "hybrid" (beta + alpha) adrenoblocker proxodolol, which is a highly effective agent for the treatment of hypertension, as well as many other original drugs for which there is medical need.

Glushkov's enormous experience in the creation of a variety of drugs and initiation of their industrial production were of great value to his work in founding and developing the Khimiko-Farmatsevticheskii Zhurnal. As Editor in Chief, Glushkov consistently maintained a high quality for scientific publications on the molecular biological bases of drug creation, drug discovery, manufacturing technologies, and analytical methods. Glushkov achieved recognition for the journal both in Russia and abroad, making it one of the few Russian scientific journals translated into English and distributed by Springer.

We will cherish bright memories of a responsive and intelligent human with a highly professional approach who has made important contributions to the development of drug chemistry Robert Georgievich Glushkov.

\section{Ministry of Health of the Russian Federation \\ Presidium of the Russian Academy of Medical Sciences \\ Editorial Board, Khimiko-Farmatsevticheskii Zhurnal}

